\title{
The Performance of Pelargonium Stockplants in Different Potting Mixtures ${ }^{1}$
}

\author{
Saulo J. Rodríguez and Carlos Rivera-López ${ }^{2}$
}

\begin{abstract}
The possibility of substituting peatmoss with tobacco industry residues, wood shavings, sawdust, spent ground coffee, coffee parchment, dry coffee leaves, sugarcane bagasse, or Caño Tiburones muck in potting mixture for Pelargonium stockplants was investigated. The different materials were mixed in $1: 1,1: 3$, or $3: 1$ proportions with Cataño sand or Cialitos clay (an Oxisol). Dry coffee leaves and sugarcane bagasse consistently gave as good results as peatmoss. None of the other materials tested compared favorably with peatmoss for the growth of Pelargonium stock plants.
\end{abstract}

\section{INTRODUCTION}

The value of ornamental plant production in Puerto Rico has been estimated to be around $\$ 4.26$ million. One fourth of the production is exported, mostly to the United States and Europe. Plant quarantine regulations prohibit the exportation of nursery stock in soil. For this reason, peatmoss is widely used by nurserymen in potting, bedding, and rooting media. Around $\$ 100,000$ worth of peatmoss is consumed by nurseries each year. ${ }^{3}$ It is possible, however, to grow nursery plants for local consumption in materials that do not contain peatmoss.

This paper reports some findings on the possibility of substituting different local materials for peatmoss in the production of ornamental stockplants.

\section{MATERIAL AND METHODS}

Peatmoss, tobacco industry residues, wood shavings, sawdust, spent ground coffee, coffee parchment (hulls), dry coffee leaves, sugarcane bagasse, and muck soil were mixed with either a sandy or a lateritic soil in different proportions by volume. All the materials except peatmoss are agricultural or industrial byproducts.

The materials were mixed at 1:1, 1:3, or 3:1 proportion by volume with

${ }^{1}$ Manuscript submitted to Editorial Board September 3, 1974.

${ }^{2}$ Horticulturist and Agronomist, respectively, Plant Breeding Department, Agricultural Experimental Station, Mayagüez Campus, University of Puerto Rico, Rio Piedras, P.R.

${ }^{3}$ Personal Communication from Mr. Alejandro Santiago, nursery owner and peatmoss importer. 
each of the two soils. The dry materials were handmixed thoroughly and placed in 1-gal plastic pots. The pots were placed on a working bench in a glasshouse. The temperature in the glasshouse was partially controlled by air extractors and a water cooling system. A $50 \%$ shade (Saran plastic cloth) reduced light intensity.

Irrigation was provided daily through capillary tubing attached to a $3 / 4$-in plastic water tube running along the center of the bench.

One rooted Pelargonium cutting, variety Sincerity, was placed in each 1-gal pot. The treatments were distributed by following a partially balanced incomplete block design.

The pots were fertilized weekly with a 30-10-10 fertilizer solution containing $100 \mathrm{p} / \mathrm{m}$ of nitrogen. A tablespoonful was dissolved in a gallon of tapwater. A cup of the solution was applied by hand to each pot.

The plants were hand-pinched when they were established. The cuttings were harvested, weighed, and leaf-counted biweekly, starting at the 50th day after planting.

The data were summarized and statistically analyzed. Means were compared at the $5 \%$ level.

\section{RESULTS AND DISCUSSION}

The results are presented in tables 1 and 2. The effects of the different mixtures are presented as fresh weight and in the number of commercial cuttings harvested from each stockplant.

Coffee parchment was inferior to the other potting materials with regard to fresh weights of cuttings when it was mixed with Cataño sand at a 1:3 proportion by volume. There were no significant differences between the other materials and peatmoss in the same proportion.

The plants growing in a 1:1 mixture of Cataño sand and tobacco industry residues grew as well as those with peatmoss and Cataño sand in the same proportion. The same was true for those growing in dry coffee leaves, sugarcane bagasse or muck soil in the same proportion with Cataño sand. In the 3:1 mixtures the plants growing in dry coffee leaves, sugarcane, or muck soil grew as well as those with peatmoss.

In the mixtures with the Cialitos clay, there were some unexpected differences. Spent ground coffee was the inferior material at the 1:3 proportion. The plants growing in peatmoss were not superior to those growing in the other materials. At the 1:1 proportion both coffee parchment and muck soil were inferior to peatmoss.

The plants growing in 3:1 peatmoss-Cialitos clay mixture were the best in the Cialitos soil group, but they did not differ significantly from those in sawdust, dry coffee leaves or sugarcane bagasse.

Table 2 presents the number of commercial Pelargonium cuttings 
TABLE 1.-Effect of type and proportion of potting material in two soils on growth of Pelargonium stockplants as reflected by fresh weight in grams of harvested cuttings ${ }^{1}$

\begin{tabular}{|c|c|c|c|c|c|c|}
\hline \multirow{3}{*}{ Materials } & \multicolumn{6}{|c|}{ Mixed with } \\
\hline & \multicolumn{3}{|c|}{ Cataño sand-material:soil ratios of } & \multicolumn{3}{|c|}{ Cialitos clay-material:soil ratios of } \\
\hline & $1: 3$ & $1: 1$ & $3: 1$ & $1: 3$ & $1: 1$ & $3: 1$ \\
\hline Peatmoss & $122.8 \mathrm{a}$ & $121.6 \mathrm{ab}$ & $145.2 \mathrm{a}$ & $116.5 \mathrm{a}$ & $121.1 \mathrm{a}$ & $135.8 \mathrm{a}$ \\
\hline $\begin{array}{l}\text { Tobacco industry } \\
\text { residues }\end{array}$ & $159.0 \mathrm{a}$ & $138.4 \mathrm{ab}$ & $-2.7 \mathrm{c}$ & $72.7 \mathrm{ab}$ & $76.8 \mathrm{ab}$ & $4.2 \mathrm{c}$ \\
\hline Wood shavings & $100.1 \mathrm{a}$ & $71.9 \mathrm{bc}$ & $63.6 \mathrm{bc}$ & $94.2 \mathrm{ab}$ & $89.6 \mathrm{ab}$ & $72.9 \mathrm{~b}$ \\
\hline Sawdust & $118.1 \mathrm{a}$ & $98.1 \mathrm{~b}$ & $74,6 \mathrm{~b}$ & $122.7 \mathrm{a}$ & $84.8 \mathrm{ab}$ & $113.2 \mathrm{ab}$ \\
\hline $\begin{array}{l}\text { Spent ground } \\
\text { coffee }\end{array}$ & $122.5 \mathrm{a}$ & $54.1 \mathrm{c}$ & $28.9 \mathrm{c}$ & $54.7 \mathrm{~b}$ & $68.8 \mathrm{abc}$ & $7.2 \mathrm{c}$ \\
\hline Coffee parchment & $39.2 \mathrm{~b}$ & $52.8 \mathrm{c}$ & $34.9 \mathrm{c}$ & $78.3 \mathrm{ab}$ & $35.2 \mathrm{bc}$ & $43.2 \mathrm{bc}$ \\
\hline Dry coffee leaves & $159.4 \mathrm{a}$ & $164.7 \mathrm{a}$ & $157.1 \mathrm{a}$ & $89.1 \mathrm{ab}$ & $119.8 \mathrm{a}$ & $129.2 \mathrm{ab}$ \\
\hline Sugarcane bagasse & $139.9 \mathrm{a}$ & $137.9 \mathrm{ab}$ & $153.3 \mathrm{a}$ & $103.6 \mathrm{ab}$ & $125.6 \mathrm{a}$ & $77.8 \mathrm{ab}$ \\
\hline Muck soil & $118.4 \mathrm{a}$ & $133.5 \mathrm{ab}$ & $118.1 \mathrm{ab}$ & $65.3 \mathrm{ab}$ & $14.6 \mathrm{c}$ & $19.5 \mathrm{bc}$ \\
\hline
\end{tabular}

${ }^{1}$ Means with a letter in common do not differ significantly at the $5 \%$ level.

TABLE 2.-Effect of type and proportion of potting materials on the number of commercial Pelargonium cuttings produced per pot ${ }^{2}$

\begin{tabular}{|c|c|c|c|c|c|c|}
\hline \multirow{3}{*}{ Materials } & \multicolumn{6}{|c|}{ Mixed with } \\
\hline & \multicolumn{3}{|c|}{ Cataño sand at rates of } & \multicolumn{3}{|c|}{ Cialitus clay at rates of } \\
\hline & $1: 3$ & $1: 1$ & $3: 1$ & $1: 3$ & $1: 1$ & $3: 1$ \\
\hline Peatmoss & $8.8 \mathrm{a}$ & $8.1 \mathrm{a}$ & $7.5 \mathrm{a}$ & $7.5 \mathrm{ab}$ & $8.4 \mathrm{a}$ & $9.8 \mathrm{a}$ \\
\hline $\begin{array}{l}\text { Tobacco industry } \\
\text { residues }\end{array}$ & $9.7 \mathrm{a}$ & $9.0 \mathrm{a}$ & $-0.8 \mathrm{c}$ & $6.3 \mathrm{abc}$ & $4.9 \mathrm{abc}$ & $0.1 \mathrm{~d}$ \\
\hline Wood shavings & $7.6 \mathrm{a}$ & $3.2 \mathrm{~b}$ & $3.1 \mathrm{~b}$ & $7.2 \mathrm{abc}$ & $6.6 \mathrm{ab}$ & $5.0 \mathrm{abc}$ \\
\hline Sawdust & $7.7 \mathrm{a}$ & $8.2 \mathrm{a}$ & $4.0 \mathrm{~b}$ & $7.6 \mathrm{ab}$ & $6.6 \mathrm{ab}$ & $7.2 \mathrm{ab}$ \\
\hline Spent ground coffee & $8.1 \mathrm{a}$ & $3.7 \mathrm{~b}$ & $2.5 \mathrm{~b}$ & $3.9 \mathrm{c}$ & $4.0 \mathrm{bc}$ & $-0.5 \mathrm{~d}$ \\
\hline Coffee parchment & $3.9 \mathrm{~b}$ & $2.9 \mathrm{~b}$ & $2.4 \mathrm{~b}$ & $4.7 \mathrm{bc}$ & $3.8 \mathrm{bc}$ & $2.8 \mathrm{~cd}$ \\
\hline Dry coffee leaves & $7.9 \mathrm{a}$ & $9.6 \mathrm{a}$ & $11.1 \mathrm{a}$ & $6.2 \mathrm{abc}$ & $7.7 \mathrm{a}$ & $8.9 \mathrm{a}$ \\
\hline Sugarcane bagasse & $7.4 \mathrm{a}$ & $8.5 \mathrm{a}$ & $9.5 \mathrm{a}$ & $8.6 \mathrm{a}$ & $8.1 \mathrm{a}$ & $3.9 \mathrm{bc}$ \\
\hline Muck soil & $9.2 \mathrm{a}$ & $9.4 \mathrm{a}$ & $8.1 \mathrm{a}$ & $6.8 \mathrm{abc}$ & $0.6 \mathrm{c}$ & $0.7 \mathrm{~d}$ \\
\hline
\end{tabular}

${ }^{1}$ Means with a letter in common do not differ significantly at the $5 \%$ level.

harvested per pot. Coffee parchment markedly reduced the number of harvested cuttings, especially when it was mixed in a $1: 3$ proportion with Cataño sand. In the 1:1 proportion the same results were observed, but in this instance wood shavings and spent ground coffee were also significantly unfavorable. In the $3: 1$ proportion dry coffee leaves, sugarcane bagasse, and muck soil were as good as peatmoss.

The mixture of spent ground coffee and Cialitos clay in a 3:1 proportion significantly reduced the number of commercial cuttings. At 
the $1: 1$ proportion spent ground coffee was again inferior, but at this level it was accompanied by coffee parchment and muck soil. At the 3:1 proportion only wood shavings, sawdust, and dry coffeee leaves produced as good results as peatmoss.

The performance of Pelargonium stockplants in peatmoss and some native potting materials was favorable. Dry coffee leaves, sugarcane bagasse or muck soil consistently proved to be a suitable substitute for peatmoss in potting mixtures. Availability and cost of handling are factors that may reduce their possibilities. Nevertheless, nurseries close. to the different sources can benefit from them. The raw materials can be easily stored for a thorough curing after which they can be used in mixtures for local outlets.

\section{RESUMEN}

Esquejes arraigados de Pelargonium se sembraron en tiestos plásticos de un galón de capacidad en un invernadero. Los tiestos contenían distintas mezclas para el medio de crecimiento, incluyendo musgo turboso. Esquejes de dichas plantas se cosecharon a intêrvalos regulares anotándose el número y peso fresco de los esquejes. Los resultados revelaron que varias materias y proporciones eran tan buenas como el musgo turboso para el crecimiento de plantas de Pelargonium como plants madres. La hojarasca de café seca o bagazo de caña de azúcar fueron consistentemente tan buenas como el musgo turboso. El pergamino y las borras de café asi como los desperdicios del despalillado de tabaco siempre afectaron adversamente el crecimiento. La viruta de madera, aserrín o un suelo orgánico (turba Tiburones) fueron detrimentales para el crecimiento en varias proporciones con los dos suelos usados (arena Cataño y arcilla Cialitos). Las plantas que se sembraron en mezclas que contenían musgo turboso, hojarasca de café o bagazo de caña de azúcar no se afectaron en las proporciones usadas. Las plantas sembradas en las mezclas que contenían los desperdicios del despalillado de tabaco, borras o pergamino de café consistentemente crecieron menos a medida que la materia estudiada aumentaba, Las sembradas en mezclas que contenían viruta de madera, aserrín o el suelo orgánico muchas veces no desarrollaron bien a medida que la cantidad del suelo aumentaba. 